УДК 792.075:792.54:7.067.3:7.091.4
DOІ https://doi.org/10.31723/2524-0447-2021-32-1-8

Олексій Юрійович Гончар

ORCID: 0000-0001-5353-0644

магістр культурології,

аспірант кафедри теорії та історії музичного виконавства

Національної музичної академії України імені П. І. Чайковського

alexeygonchar412@gmail.com

\title{
«НОВИЙ БАЙРОЙТ» - ВІДРОДЖЕННЯ ВАГНЕРІВСЬКОГО ФЕСТИВАЛЮ: ПЕРЕДУМОВИ, ПЕРСОНАЛІЇ
}

Мета роботи - дослідити маловивчений у пострадянському музикознавстві елемент творчого спадку Ріхарда Вагнера, а саме авторський Байройтський фестиваль, який був започаткований 1876 року задля створення концептуальних умов для виконання тетралогії «Перстень Нібелунга» та став центром вагнерівського мистеитва. У ХХ столітті він опинився у складних обставинах через залучення до політичних процесів, що мали місце у Німеччині й загрожували його існуванню після завершення війни. Акцентом цієї роботи є висвітлення історичних умов функціонування Байройтського фестивалю починаючи від 20-х рр. ХХ століття та його повоєнного відновлення у 1951 році. Методологія роботи трунтується на аналізі історичного контексту та музично-історичних умов і використанні порівняльно-описових методів стосовно довоєнного та післявоєнного бачення постановниками своїх мистецьких підходів до сиенічного втілення музичної драми Р. Вагнера. Наукова новизна дослідження полягає у зверненні до невід'ємного аспекту творчості Р. Вагнера, який в україномовному та російськомовному музикознавстві є малодослідженим. Автори, роботи яких присвячені постаті та творчості Р. Вагнера, серед них - М. Черкашина-Губаренко, О. Бабій, А. Єфименко, Л. Мудрецька, О. Наумова, O. Рощенко, I. Богданова, М. Забара та ін., охоплюють переважно музичну проблематику, оминаючи важливий з точки зору композитора елемент відповідних умов для втілення його творів, що був створений у Фестшпільхаузі міста Байройт. Єдина робота з історії Фестивалю часів Р. Вагнера та К. Вагнер належить М. Черкашиній-Губаренко [1]. Висновки. Історія Байройтського фестивалю у XX столітті видалась драматичною та тісно вплетеною в політичні процеси Німеччини. Перша половина століття та мистецька діяльність керівників Фестивалю була орієнтована на слідування зразкам перших прижиттєвих авторських постановок, збереження традиції. 3 кіния 20-х років Байройт

(C) Гончар О. Ю., 2021 
опиняється втягнутим у зростаючий авторитет нацистської ідеології, а після смерті Зігфріда Вагнера 1930 року та симпатій його дружини Вініфред до керівника партії й пануючої ідеології цей процес посилюється. Незважаючи на такий стан речей, мистецтво лишалось відокремленим від ідеології та політики, наскільки це було можливим. Повоєнне становище містило загрозу щодо можливості продовження діяльності Фестивалю, але призначення на посаду керівників не заплямованих у політичній діяльності онуків Вагнера дозволило уникнути цього. Оновлена мистецька політика сприяла становленню Фестивалю як одного $з$ інноваційніших центрів оперного мистецтва.

Ключові слова: Байройтський фестиваль, Новий Байройт, Ріхард Вагнер, Козіма Вагнер, Зігфрід Вагнер, Вініфред Вагнер, Віланд Вагнер, Вольфганг Вагнер.

Honchar Oleksii Yuriiovych, Master of Cultural Studies, Postgraduate Student at the Department of Theory and History of Music Performance of the Ukrainian National Tchaikovsky Academy of Music

"New Bayreuth" - the revival of the R. Wagner's Festival: the prerequisites, the personality

Research objective of this work is to study an element of the creative heritage of Richard Wagner, little studied in post-Soviet musicology, namely the author's Bayreuth Festival, which was founded in 1876 with the aim of creating conceptual conditions for performing the tetralogy "Ring of the Nibelungen" and became the centre of Wagnerian art. In the twentieth century, it turned up in difficult conditions due to involvement in the political processes took place in Germany and threatened its existence at the end of the war. The focus of this work is to highlight the historical conditions of the Bayreuth Festival since the 1920s and its post-war reconstruction in 1951. The methodology of the work is based on the analysis of the historical context and musical-historical conditions, as well as the use of comparative-descriptive methods in relation to the pre-war and post-war types by the directors of their artistic approaches to the stage embodiment of the musical drama of $R$. Wagner. The scientific novelty of the research lies in the appeal to an integral aspect of $R$. Wagner's work, which is little studied in the Ukrainian-speaking and Russian-speaking musicology. The authors, whose works are devoted to the figure and creativity of R. Wagner, including M. Cherkashina-Gubarenko, A. Babiy, L. Mudretska, A. Naumova, A. Roshchenko, I. Bogdanova, M. Zabara etc., cover mainly musical problems, bypassing the important element from the point of view of the composer, - the appropriate conditions for the embodiment of his works, which was created in the Festspielhaus of the city of Bayreuth. The only work on the history of the Festival of the times of R. Wagner and K. Wagner belongs to M. Cherkashina-Gubarenko [1]. Conclusions. The history of the Bayreuth Festival in the twentieth century turned out to be dramatic and closely intertwined with the political processes of Germany. The first half of the century and the artistic activity of the directors of the Festival was focused on following the samples of the first lifetime author's performances, preserving the tradition. Since the late 1920s, Bayreuth has been drawn into the growing 
authority of Nazi ideology, and after the death of Siegfried Wagner in 1930 and the sympathies of his wife Winifred for the party leader and the dominant ideology, this process intensifies. Despite this state of affairs, art remained as separated from ideology and politics as possible. The post-war situation threatened the continuation of the Festival, but the appointment of the leaders of Wagner's grandchildren, untainted in political activity, made it possible to avoid this. The renewed artistic policy of the Festival allowed it to become one of the most innovative centres of opera art.

Key words: Bayreuth Festival, New Bayreuth, Richard Wagner, Cosima Wagner, Siegfried Wagner, Winifred Wagner, Wieland Wagner, Wolfgang Wagner.

Актуальність дослідження. Натепер українські музикознавці звернули увагу на комплекси та засоби інфраструктурних і позамузичних елементів, без яких виконання творів неможливе в традиційний для європейської культури спосіб. Це вивчення музичного простору, фестивалів та сучасних медіазасобів трансляції музики, включаючи такий метажанр, як опера. При цьому німецькомовній частині інфраструктурних утворень, у тому числі оперним фестивалям, надається значно менша увага, незважаючи на те, що нині саме ця територія $є$ лідером в оперній індустрії. Автор має на меті дослідження Байройтського фестивалю та музичної спадщини Ріхарда Вагнера, яка багато в чому визначила шляхи розвитку жанру опери у XX столітті. Цей пласт культурного надбання тривалий час не мав актуальності та не був досить вивчений, що породило прірву між європейським та пострадянським музикознавством щодо розробки такого матеріалу.

Мета роботи - дослідити маловивчений у пострадянському музикознавстві елемент творчого спадку Ріхарда Вагнера, а саме авторський Байройтський фестиваль, який був започаткований 1876 року задля створення концептуальних умов для виконання тетралогії «Перстень Нібелунга» та став центром вагнерівського мистецтва. У XX столітті він опинився у складних обставинах через залучення до політичних процесів, що мали місце у Німеччині й загрожували його існуванню після завершення війни. Акцентом цієї роботи є висвітлення історичних умов функціонування Байройтського фестивалю починаючи від 20-х pp. XX століття та його повоєнного відновлення у 1951 році онуками композитора.

Наукова новизна дослідження полягає у зверненні до невід'ємного аспекту творчості Р. Вагнера, який в україно- 
мовному та російськомовному музикознавстві $є$ малодослідженим. Автори, роботи яких присвячені постаті та творчості Р. Вагнера, серед них - М. Черкашина-Губаренко, О. Бабій, А. Єфименко, Л. Мудрецька, О. Наумова, О. Рощенко, І. Богданова, М. Забара та ін., охоплюють переважно музичну проблематику, оминаючи важливий з точки зору композитора елемент відповідних умов для втілення його творів, що був створений у Фестшпільхаузі міста Байройта.

Виклад основного матеріалу. Творчий спадок Р. Вагнера у першій половині XX століття був популярним та виконувався майже в усіх великих театрах Європи та Америки. Паралельно до світової практики виконання вагнерівських творів існувала традиція, започаткована самим композитором у рамках Байройтського фестивалю, який був створений Р. Вагнером задля постановки «Перстня Нібелунга» у 1876 році. Після смерті автора у Венеції 1883 року керівництво Фестивалем взяла у свої руки вдова митця Козіма Вагнер (1837-1930). Як відомо, Козіма Вагнер постійно декларувала свій намір зберегти в Байройті все так, як було за Ріхарда Вагнера, - виконавська традиція та принципи постановок майже не зазнали змін, наслідуючи принципи тих спектаклів, які були створені за життя Р. Вагнера, хоча до кінця реалізувати це було неможливо.

За їі керівництва, окрім поставлених на фестивальній сцені за Р. Вагнера тетралогії «Перстень Нібелунга» та «Парсифаля», були вперше здійснені постановки «Трістана та Ізольди» (1886), «Нюрнберзьких мейстерзінгерів» (1888) ${ }^{1}$, «Тангойзера» (1891) та «Лоенгріна» (1894), «Летючого Голландця» (1901 режисерський дебют Зігфріда Вагнера), їй належить і друга в історії Фестивалю постановка «Перстня» 1896 року. Усі ці спектаклі зберігалися в репертуарі тривалий час.

Діяльність Козіми на посту керівника спочатку зустріла гостре несприйняття. Їй дорікали узурпацію влади та навіть не німецьке походження. Яскраво ілюструють цей важкий період спогади Зігфріда: «Найбільш сильне цькування з усіх боків почалось тоді, коли мати повідомила про постановку «Тангойзера». <...> Спочатку обурення викликав сам факт появи цієї опери у Байройті, адже це твір юності, ще наполовину

1 Цю постановку здійснив Август Харлахер (1842-1907), оперний співак та режисер - вперше запрошений до Байройта постановник. 
стара опера. Вороги та фальшиві друзі намагалися дискредитувати мою матір перед публікою. Справжній відьомський шабаш супроводжував прем'єру. Але рік постановки «Тангойзера» був вирішальною битвою, й моя матір перемогла. $<\ldots>$ Але особливо осуджувалося запрошення іноземних співаків...» [12, с. 79].

Козіма Вагнер у 1908 році передала керівництво сімейною справою синові Зігфріду (1869-1930). Він усвідомлював, що традиціоналізм, якому слідувала його матір, застарів та намагався проводити поступову модернізацію вистав. Наслідуючи традиції постановок, що склалися за його батька і були продовжені матір'ю, він усе ж здійснив деякі важливі нововведення в театральній структурі вистав, оновив технічне оснащення театру. 3 початком Першої світової війни Фестиваль не проводився до 1923 року, після відновлення став більш регулярним, а з 1936 року - щорічним.

3 кінця 20-х років у Німеччині відбуваються політичні процеси, які зачіпають погляди Р. Вагнера. Особливо це стосується його антисемітських переконань, які стають частиною ідеологічного підгрунтя націонал-соціалізму. Слід зауважити, що погляди чоловіка розділяла й Козіма, а обстановка того часу була сприятливою для культивування цих переконань, що пізніше в політичному курсі обернеться у трагедією Холокосту. Якщо Зігфрід не мав симпатій до цієї політичної ідеї, то його дружина Вініфред Вагнер (уроджена Уільямс, 1897-1980), навпаки, симпатизувала цим ідеям та особисто А. Гітлеру, з яким мала доволі тісні дружні стосунки. Вініфред стала на чолі Фестивалю після раптової смерті у 1930 році їі чоловіка Зігфріда й залишалась на цій посаді аж до завершення фестивальної діяльності у другій половині 1944 року. Саме цей період видався найбільш важким та суперечливим з погляду на майбутнє Фестивалю й вагнерівського мистецького спадку, що опинився серед «обвинувачених» спільників режиму.

До 1939 року вистави Фестивалю продовжувала відвідувати іноземна публіка, серед виконавців усе ще лишались іноземні артисти, але $з$ початком воєнних дій та закриття кордонів ситуація кардинально змінилась. Загроза припинення діяльності, як було за часів Першої світової, була очевидною, але Гітлер особисто обіцяв Вініфред фінансування Фестивалю у необхідних розмірах, на що вона врешті погодилась. Воєнний 
час, який отримав назву «фестивалю війни», не був сприятливим для мистецького розвитку. Попри прийнятну фінансову стабільність, репертуар скоротився і в останній рік проведення - 1944 - складався лише 3 «Нюрнберзьких мейстерзінгерів». Проведення вистав дозволило зберегти обладнання та належним чином обслуговувати приміщення, а також забезпечити роботою персонал, одночасно позбавивши його обов'язку військової служби.

5 квітня 1945 року відбувся перший наліт американської авіації на Байройт, внаслідок чого вілла Ванфрід була зруйнована на третину, а 14 квітня американські солдати окупували місто. Фестшпільхаус і будинок Зігфріда Вагнера було реквізовано, деякий час вони використовувались для військових зборів. Вініфред Вагнер як керівника фестивалю заарештовують, інкримінуючи участь у політичній діяльності і посібництві режиму. Ідеологізація постаті Р. Вагнера та Байройтського фестивалю як місця «торжества німецького духу»² могли унеможливити відновлення фестивальної діяльності, проте саме позиція Вініфред дозволила відкрити нову сторінку в історії проведення Фестивалю.

На судових процесах, які розпочалися в післявоєнній Німеччині 1947 року, Вініфред була звинувачена в активній підтримці та співпраці з націонал-соціалізмом. 25 червня цього ж року на слуханнях у своїй справі Вініфред подала Меморандум на свій захист. Вона відкидала всі звинувачення та мотивувала свої дії з керівництва Фестивалем лише бажанням зберегти в недоторканності заповіти Майстра й сам його задум. Намагаючись показати, що вона перебувала у пасивній опозиції до режиму, Вініфред наводила приклади, коли особисто заступалась за неблагонадійних музикантів з точки зору ідеологічної доктрини режиму. Посилалася вона на введену заборону проведення політичних мітингів у залі Фестшпільхаузу ${ }^{3}$ а також перераховувала все, що їй особисто вдалося

2 Як не парадоксально, але за часів правління Гітлера єдина функціонуюча у Німеччині синагога знаходилась у Байройті, «місті Вагнера», який став одним із мистецько-ідеологічних центрів Третього Рейху.

3 Ця заборона була введена ще 1924 року після поновлення Фестивалю, який відкрився «Нюрнберзькими мейстерзінгерами» (пост. 1911 року), де публіка після завершення спектаклю співала «Пісню німців» А.Г. Гофмана фон Фаллерслебена (1841), що на той час була програмним твором німецьких націоналістів. 
досягти задля розвитку ідеї Байройта, збереження у цілісності apхіву Р. Вагнера, збору та систематизації його документів та листів. Звісно, що повністю оминути ідеологію було неможливо, а частина гарантованого фінансування відбувалась через купівлю квитків для солдат, що було частиною пропаганди «німецького духу» [10, с. 544].

За вироком суду Вініфред була засуджена за найсуворішою статтею, але після апеляції і повторних слухань покарання було пом'якшено [13]. У зв'язку із забороною обіймати будьякі посади і брати участь у суспільному житті Вініфред Вагнер 21 січня 1949 року підписала відмову від усіх прав на Фестиваль на користь синів Віланда та Вольфганга. При цьому аж до 1973 року вона залишалась власницею Фестшпільхаусу й прилеглих до нього приміщень. Незважаючи на жорстку позицію нової влади стосовно колишньої верхівки Рейху і до їх прихильників, Вініфред продовжувала спілкування зі старими друзями, серед яких були представники вищих ешелонів влади і військові. Це спілкування кидало тінь на оновлений Фестиваль та породжувало напруження у сім'ї [11, с. 69]. Важливим кроком для подальшого відновлення діяльності фестивалю стала організація у 1949 році «Товариства друзів Байройта». Його учасники збирали кошти для фінансування Фестивалю, який почав свою нову історію 29 липня 1951 року.

Віланд передбачувано обійняв пост керівника Фестивалю, але офіційне двовладдя з братом стало новою практикою сімейної справи Вагнерів, хоча фактично ще з часу керування Зігфріда Вагнера за його спиною стояла Козіма, яка впливала на мистецьку політику сина, а Вініфред дослуховувалась точки зору Хайнца Тітьєна (1881-1967, другого за історію Фестивалю запрошеного режисера).

Дві дочки Зігфріда - Фріделінд (1918-1991) та Верена (1920-2019) не грали настільки важливих ролей у сімейному підприємстві. Так, у Фріделінд ще в 1930-і роки стався конфлікт з матір'ю, внаслідок якого вона залишила країну перед початком Другої світової війни і більше не брала участь у справах Байройта, лише раз відвідавши його у 1990 році. Їі особисті проєкти були пов'язані з музикою як Ріхарда, так і Зігфріда Вагнера, чиї твори вона популяризувала. Фріделінд вже у 1945 році напише автобіографічну книгу «Спадщина вогню», в якій вона продовжить гостру полеміку та викривання співпраці з нацистами своєї матері й тогочасного 
художнього керівництва Фестивалю ${ }^{4}$. Свою скромну роль грала у цьому сімейному ансамблі й молодша дочка Зігфріда та Вініфред - Верена. У 1943 році вона вийшла заміж за Бодо Лафферентца, офіцера СС, який служив в одному з культурно-ідеологічних департаментів Рейху. У повоєнний час вона входила до ради Фонду Ріхарда Вагнера й займалася адміністративною роботою Фестивалю.

Надзвичайно важливим з точки зору стратегії існування Фестивалю $є$ ідея створення Фонду Ріхарда Вагнера, яка належить Вініфред Вагнер. Навесні 1972 року вона виступила із заявою про необхідність створення Фонду з метою збереження цілісності архіву, театру та вілли Ванфрід. У веденні Фонду перебуває управління Байройтським фестивалем, усі фінансові та адміністративні справи, включаючи призначення керівників.

Переходячи до поновлення Байройтського фестивалю у 1951 році, варто зазначити важливу роль Вініфред Вагнер як керівника та ії діяльність саме з мистецької точки зору. Щоб зрозуміти, які перепони цьому передували, слід звернути увагу на останні роки керівництва Фестивалем, здійснюваного Вініфред. Роблячи оцінку їі діяльності тепер, неможливо не враховувати умови тотально-контрольованої культурної політики, в яких їй доводилось працювати. Державна система контролювала всі аспекти життя, а особливо активно втручалась у питання мистецтва, яке слугувало ідеології. У театрів та концертних організацій не було можливості вільного вибору репертуару, запрошення виконавців, ведення адміністративної роботи. 3 огляду на це, можна особливо оцінити заслугу Вініфред Вагнер у збереженні Фестивалю.

Вона використовувала свій вплив та особисті зв’язки задля супротиву повній політизації очолюваного нею підприємства. Байройт зберіг статус незалежного (наскільки це було можливо) культурного центру, адже не увійшов до Театрального департаменту Рейху та підконтрольні йому структури. Вініфред вдалося уникнути вступу до департаменту, що викликало б стандартну фінансову та адміністративну залежність від держави. Нерідко вона дозволяла собі ігнорувати розпорядження державних органів, що відповідали за культуру та іде-

4 Більш детально: Weissweiler, Eva: Erbin des Feuers. Friedelind Wagner - Eine Spurensuche. München : Pantheon Verlag, 2013. 368 S. 
ологію, користувалася каналами фінансування поза апаратом розподілу коштів. Така її поведінка була можливою через особистий та доволі тісний контакт з Адольфом Гітлером, який обожнював музику Вагнера. У довоєнні роки фюрер часто відвідував Байройт і гостював на віллі Ванфрід та у будинку, де мешкав із сім'єю Зігфрід 5 . Особисті симпатії Вініфред до дружньо налаштованого до неї диктатора, тим не менш, завершувались, коли мова заходила про творчий спадок Вагнера.

Провідна роль у відродженні Фестивалю і подальшому його розвитку в повоєнний час належить Віланду Вагнеру (Wieland Adolf Gottfried Wagner; 1917-1966). Віланд був першою дитиною Зігфріда Вагнера та Вініфред. Він здобув освіту живописця та фотографа, з молодого віку брав участь у оформленні сцени Байройтського фестивалю (1937 р. «Парсифаль», 1943 р. - «Нюрнберзькі мейстерзінгери»), став «обличчям» Фестивалю після його відновлення у 1951 році, розділяючи управління з братом Вольфгангом (Wolfgang Manfred Martin Wagner, 1919-2010). Аж до смерті Віланда в 1966 році молодший за нього Вольфганг займався переважно адміністративною роботою і надзвичайно важливими для того часу фінансовими питаннями, хоча частково брав участь і в художній діяльності. Режисерським дебютом Вольфганга була постановка «Лоенгріна» 1953 року. Як і старший брат, він вчився театральних мистецтв у Мюнхені, паралельно вивчаючи музику. Сценічні роботи Вольфганга мали спільні риси 3 роботами брата, хоча були не такими аскетичними щодо сценографії. «Віланд і Вольфганг Вагнери - несхожі один на одного брати: один з живописним баченням, інший з практичним, організаційним і комерційним талантом ... Нові співаки, нові диригенти і абсолютно нові режисерські концепції переїхали в Байройтський фестивальний зал...» [8].

До сценографічної практики Віланд уперше вдався 1935 року, створивши декорації для театрів Любека, Кельна та Альтенбурга. Перші байройтські роботи двадцятирічного Віланда над сценографією третьої постановки «Парсифалю» (сценографія та костюми) під керівництвом Вільгельма Фуртвенглера 1937 року стали показником безсумнівного таланту юнака [9, с. 638]. 31937 по 1943 рік Віланд вчиться візуальних мистецтв у Мюнхені, а з 1940 бере уроки музики у

5 Будинок Зігфріда Вагнера ліворуч від Ванфріда. 
Курта Оверхоффа (1902-1986) - австрійського диригента та композитора, який раніше був помічником В. Фуртвенглера у Віденській опері. Курт Оверхофф буде музичним асистентом на Фестивалі 1951 року, але критично віднесеться до поставленого Віландом «Парсифалю», після чого їхні стосунки припиняться [7, с. 96]. Перша постановка «Перстня Нібелунга» була здійснена Віландом 1943 року у Земельному театрі (Landestheater) Альтенбурга.

Як представник нової генерації Вагнерів Віланд зростав у нових реаліях XX століття. Він не зазнав такого впливу мистецьких переконань своєї бабусі Козіми, яка померла, коли онукові було 13 років. У своїх роботах Віланд Вагнер приділяв велику увагу не зовнішньому вигляду твору, а скоріше його внутрішньому змісту та динамізму. У новаціях він слідував ідеям Адольфа Аппіа (1862-1928). Після відвідин Байройта у 1890-х швейцарський сценограф і театральний реформатор звернув увагу на невідповідність декларованих Р. Вагнером концепцій «музичної драми майбутнього» 3 фактичним результатом. На його думку, притаманні музиці Вагнера безперервний розвиток і глибока внутрішня енергія губилися за декораціями та режисерською інтерпретацією ілюстративного характеру. Прагнення Зігфріда Вагнера модернізувати вистави шляхом розвантаження їх від безлічі сценічних деталей були надто обережні.

Віланд Вагнер активно використовував думку А. Аппіа про необхідність виходити у сценічному оформленні вагнерівських опер з музики, шукати шляхів візуалізації музичних образів та філософських символів. Віланд докорінно спростив декорації і надавав великого значення світлу. При цьому його довоєнні досліди як сценографа в Байройті хоч і були зв'язані режисерським баченням Хайнца Тітьена, та все ж мали передумови до модернізації візуального образу вистави. Наприклад, сценографія для байройтської постановки «Парсифаля» 1937 року хоча і слідувала зразкам постановки 1882 року, але в окремі сцени Віланд вводив абсолютно нові для того часу кінопроєкції.

Неможливо випустити з біографії Віланда Вагнера й роки правління в Німеччині нацистів. У юності він перебував в оточенні, де не міг уникнути певного впливу пануючої ідеології. Разом із тим більшість джерел говорить про його аполітичність. У підлітковому віці Віланд знав диктатора як «дядька 
Вольфа», адже той бував у будинку Вагнерів, бачив у Віланді зразкового німецького юнака та «ідеального сина» [6]. Iз вступом Гітлера на посаду Рейхсканслера його спілкування із сім'єю Вагнерів стало більш формальним, а візити в Байройт набули офіційного статусу. За наполяганням матері Віланд Вагнер у 1933 році вступив до Гітлерюгенду. У 1938 році він стає членом НСДРП (членський квиток № 6078301). Адольф Гітлер особисто звільнив його від військової служби. На відміну від старшого брата, Вольфганг не був членом НСДРП та не уникнув обов'язкових для того часу трудової повинності на пів року та служби у Вермахті, куди він був призваний одразу з початком воєнних дій 1939 року. Доволі швидко отримавши поранення, він демобілізувався й став здобувати освіту у Мюнхені ${ }^{6}$.

Віланд Вагнер використовував свій доступ до фюрера у боротьбі за владу в Байройті, нейтралізації впливу своєї матері, художнього керівника Хайнца Тітьена та художника-постановника Еміля Преторіуса, які дотримувались більш консервативних поглядів на втілення музичної драми, орієнтувалися на спектаклі, створені на основі перших постановок.

У сезоні 1943/1944, під час так званого «фестивалю війни», Віланд Вагнер створив декорацію для «Нюрнберзьких мейстерзінгерів» - єдиної опери Р. Вагнера, яка тоді виконувалась. Зрозуміло, що ця остання воєнна постановка була ангажована політичним підтекстом. 3 вересня 1944 року по квітень 1945 року Віланд Вагнер проходив військову службу в «Інституті фізичних досліджень» (Institut fbr Physikalische Forschung), заснованому його зятем - чоловіком Верени Вагнер Бодо Лафферентцем у таборі Флоссенбюрг, супутнику Байройта. Ця робота дозволяла уникнути призову на фронт. У концтаборі, де ув'язнені використовувалися для примусової праці і були зобов'язані виробляти системи управління для ракет Фау-2, Віланд продовжував займатися пошуками нововведень для сценічного оформлення. За допомогою ув'язненого інженера-електрика Ганса Імхофа він проєктує моделі сучасних декорацій та нових систем освітлювальних приладів. Точні подробиці роботи Віланда у Інституті відсутні, але ско-

6 Більш детально щодо постаті Вольфганга: Carr, Jonathan. The Wagner Clan: The Saga of Germany's Most Illustrious and Infamous Family. Atlantic Monthly Press, 2007. 409 p. 
ріше за все він обіймав посаду «заступника цивільного директора» $[4$, с. $479-484]$.

8 квітня 1945 року, за три дні до закриття табору, Віланд Вагнер виїхав в Нуссдорф на Боденському озері і залишався у французькій окупаційній зоні після закінчення війни аж до 13 листопада 1948 року. Ці дії, ймовірно, були пов'язані 3 бажанням уникнути більш суворого процесу денацифікації, який мав би для нього більш серйозні наслідки, адже зв'язки сім'ї та особливо матері з верхівкою Третього Рейху надалі могли позначитися на його долі. Проте під час проходження денацифікації Віланд мовчав про роботу в концентраційному таборі та про свої зв'язки з Адольфом Гітлером, якого він востаннє відвідав у грудні 1944 року в рейхсканцелярії у Берліні. На слуханні у справі 10 грудня 1948 року у Байройті Віланд Вагнер був класифікований як «послідовник» - четверта i найнижча категорія тих, хто мали причетність до нацистського режиму.

Віланда можна вважати одним із засновників сучасного режисерського театру. Як режисер і сценічний дизайнер (сценографія та костюми) він замінив пануючий до того на сцені Байройта натуралізм символікою узагальненої дії з глибоким психологічним опрацюванням образів персонажів. Вносячи новаторські ідеї до спектаклів, він не боявся порушувати традиції і часом був навмисно провокаційним. Його революційні постановки викликали крайні погляди, думки як за, так і проти: «Тоді цей стиль був для всіх абсолютно новим. Простота, мізансцени та гра. Віланд володів талантом вибудови акторського виконання, виходячи з індивідуальності своїх співаків. Й у нього ніколи не зустрінеться зайвого ходу. Кожен рух щось означає. Те ж саме 3 голосом та співом. Це було щось зовсім нове» [5].

Перевагою нового постановочного стилю було те, що головним елементом у ньому стала музика. Сценічна дія була виразно стисненою, підкреслювалася осмисленими і лаконічними жестами та рухами. Такий підхід дозволяв створювати драматичне напруження. Майже порожня сцена його ранніх вистав найчастіше оформлялася в темних тонах, на тлі яких рельєфно виглядали силуети виконавців. Простота декорацій та костюмів без зайвої деталізації позитивно впливали на показ і більш детальну розробку кожного образу. Віланд та Вольфганг у створенні постановок розкривали до того прихо- 
вані риси персонажів, їхніх характерів та взаємодії на сцені. Завдяки такому підходу й досягався той самий ефект «сценічної напруги», що рухав невпинне розгортання вистави.

Повоєнний Байройт відкрився поставленим Віландом «Парсифалем», абсолютно не схожим на попередні постановки. Особливості цієї вистави надалі стануть стилістичним стартом режисерської діяльності Віланда. Вплив ідей А. Аппіа відчувався через увагу до світлових ефектів, якими надалі Віланд завжди буде користуватися, внутрішньою енергією і розвитком драматургії, тонко сплетеним 3 музикою. Мінімалістичні декорації простих форм і без дрібних деталей, 3 порожнім задником-циклорамою, відповідним чином освітлені дозволяли зосереджуватися виключно на виконавцях. 3 Віландом у Байройт повертаються співаки з інших країн.

У «Новому Байройті», як його стали називати невдовзі після відкриття Фестивалю 29 липня 1951 року, Віланд, зі зрозумілих причин, максимально нівелював можливі політичні підтексти виконуваних музичних драм - згодом запрошені режисери (Йоахім Герц, Рут Бергхаус, Стефан Хергейм, автор «Перстню» століття» Патріс Шеро) стали акцентувати час, робити посилання на сучасність і нещодавні історичні події, надавали гостру злободенність своїм роботам [2].

Висновки. Історія Байройтського фестивалю у XX столітті видалась драматичною та тісно вплетеною в політичні процеси Німеччини. Перша половина століття та мистецька діяльність керівників Фестивалю була орієнтована на слідування зразкам перших прижиттєвих авторських постановок, збереженні традиції. 3 кінця 20 -х років Байройт опиняється втягнутим у зростаючий авторитет нацистської ідеології, а після смерті Зігфріда Вагнера 1930 року та симпатій його дружини Вініфред до керівника партії й пануючої ідеології цей процес посилюється. Незважаючи на такий стан речей, мистецтво лишалось відокремленим від ідеології та політики, наскільки це було можливим.

Перемога над Німеччиною та визнання керівника Фестивалю причетним до злочинів режиму могло викликати повне закриття його діяльності, але мета збереження спадку Р. Вагнера та призначення не заплямованих у політичній діяльності Віланда та Вольфганга Вагнерів на посаду керівників дозволили уникнути цього. Оновлений Фестиваль виявився абсолютно не схожим на довоєнний за мистецькою політикою, 
що дозволило йому стати одним із інноваційніших центрів, що працюють у царині оперного мистецтва.

\section{СПИСОК ЛІТЕРАТУРИ}

1. Черкашина-Губаренко М.Р. Вагнерівський фестиваль у Байройті: сторінки історії. Аспекти історичного музикознавства VI: Музика і театр в історичному часі $і$ просторі. Харків : ХНУМ імені I.П. Котляревського, 2013. С. 226-244.

2. Berry M. 'Politics', first published in The Cambridge Wagner Encyclopedia / ed. Nicholas Vazsonyi. Cambridge : Cambridge University Press, 2013. URL: https://boulezian.blogspot.com/2020/07/wagner-andpolitics.html (дата звернення: 10.10.2020).

3. Carr J. The Wagner Clan: The Saga of Germany's Most Illustrious and Infamous Family. Atlantic Monthly Press, 2007. 400 p.

4. Hamann B. Winifred Wagner oder Hitlers Bayreuth. Piper Taschenbuch; Ungekürzte Taschenbuchausg. Edition, 2003. 688 S.

5. Heil dir, Sonne! Meant Something in those Conditions by Erling E. Guldbrandsen and Per-Erik Skramstad. Interview with Penelope Turning. URL: https://www.wagneropera.net/interviews/penelope-turinginterview.htm (дата звернення: 05.12.2020).

6. Hitler sah in Wieland einen Idealsohn. Redaktion, 11.10.2016. 15:43 Uhr. Interview mit Nike Wagner. URL: https://www.kurier.de/inhalt. quot-hitler-sah-in-wieland-einen-idealsohn-quot.d529e277-2cb6-4733a87a-975ef4fd7aa4.html (дата звернення: 19.01.2021).

7. Kapsamer I. Wieland Wagner, Wegbereiter und Weltffekt. Graz: Verlag Styria, 2010. 416 S.

8. Kinder! macht Neues! 125 Jahre Bayreuther Festspiele -50 Jahre Neubayreuth. Folge 8: Das Neubayreuther Wunder/Wiedererцffnung der Richard-Wagner-Festspiele 1953. Deutsche Welle. 07.11.2001. URL: https://www.dw.com/de/kinder-macht-neues/a-320368 (дата звернення: 29.11.2020).

9. Klee E. Das Kulturlexikon zum Dritten Reich. Wer war was vor und nach 1945. Frankfurt am Main: S. Fischer Verlag, 2007. 715 S.

10. Mühlenfeld D. Was heißt und zu welchem Ende studiert man NSPropaganda? Neuere Forschungen zur Geschichte von Medien, Kommunikation und Kultur während des Dritten Reiches. Archiv für Sozialgeschichte 49, 2009. URL: https://www.fes.de/index.php?eID=dumpFile\&

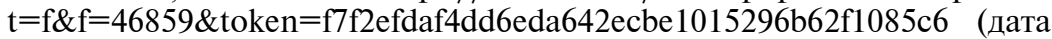
звернення: 12.08.2020).

11. Wagner G. Wer nicht mit dem Wolf heult - Autobiographische Aufzeichnungen eines Wagner-Urenkels. Köln : Kiepenheuer \& Witsch, 1997. $408 \mathrm{~S}$.

12. Wagner S. Erinnerungen. Siegfried Wagner. Frankfurt/Mein: Peter Lang GmbH : Europāischer Verlagder Wissenschaften, 2005. $128 \mathrm{~S}$.

13. Weichen für die Festspielstadt gestellt. Der Bayreuther Anwaltverein besteht seit 100 Jahren. Der Jurist Fritz Meyer paukte Winif- 
red Wagner raus. Norbayerischer Kurier, Donnerstag 5. Juli 2011. URL: https://www.bayreuther-anwaltverein.de/files/media/downloads/ Pressemitteilungen/05_07_2018_kul_16_bee36315e2.pdf (дата звернення: 20.08.2020).

14. Weissweiler E. Erbin des Feuers. Friedelind Wagner - Eine Spurensuche. München : Pantheon Verlag, 2013. 368 S.

\section{REFERENCES}

1. Cherkashina-Gubarenko, M.R. (2013). Wagnerivskiy festival u Bayroiti: storinky istoriy. Aspectu istirychnigo musycoznavstva VI: Muzyka i teatr v istorychnomu chasi i prostori. Kharkiv: KhNUM imeni I.P. Kotliarevskoho. P. 226-244 [in Ukrainian].

2. Berry, M. (2013). 'Politics', first published in The Cambridge Wagner Encyclopedia / ed. Nicholas Vazsonyi. Cambridge: Cambridge University Press. Retrieved from: https://boulezian.blogspot.com/2020/07/ wagner-and-politics.html [in English].

3. Carr, J. (2007). The Wagner Clan: The Saga of Germany's Most Illustrious and Infamous Family. Atlantic Monthly Press [in English].

4. Hamann, B. (2003). Winifred Wagner oder Hitlers Bayreuth. Piper Taschenbuch; Ungekürzte Taschenbuchausg. Edition [in German].

5. Heil dir, Sonne! Meant Something in those Conditions by Erling E. Guldbrandsen and Per-Erik Skramstad. Interview with Penelope Turning. Retrieved from: https://www.wagneropera.net/interviews/penelopeturing-interview.htm [in English].

6. Hitler sah in Wieland einen Idealsohn. Redaktion, 11.10.2016. 15:43 Uhr. Interview mit Nike Wagner. Retrieved from: https://www.kurier.de/inhalt.quot-hitler-sah-in-wieland-einen-idealsohnquot.d529e277-2cb6-4733-a87a-975ef4fd7aa4.html [in German].

7. Kapsamer, I. (2010). Wieland Wagner, Wegbereiter und Weltffekt. Graz: Verlag Styria [in German].

8. Kinder! macht Neues! 125 Jahre Bayreuther Festspiele-50 Jahre Neubayreuth. Folge 8: Das Neubayreuther Wunder/Wiedererцffnung der Richard-Wagner-Festspiele 1953 Deutsche Welle. 07.11.2001. Retrieved from: https://www.dw.com/de/kinder-macht-neues/a-320368 [in German].

9. Klee, E. (2007). Das Kulturlexikon zum Dritten Reich. Wer war was vor und nach 1945. Frankfurt am Main: S. Fischer Verlag [in German].

10. Mühlenfeld, D. (2009). Was heißt und zu welchem Ende studiert man NS-Propaganda? Neuere Forschungen zur Geschichte von Medien, Kommunikation und Kultur während des Dritten Reiches. Archiv für Sozialgeschichte 49. Retrieved from: $h t t p s: / / w w w . f e s . d e / i n d e x . p h p ? e I D=d u m p F i l e \& t=f \& f=46859$ \&token=f7f2efdaf4dd6eda642ecbe1015296b62f1085c6 [in German].

11. Wagner, G. (1997). Wer nicht mit dem Wolf heult - Autobiographische Aufzeichnungen eines Wagner-Urenkels. Köln: Kiepenheuer \& Witsch [in German].

12. Wagner, S. (2005). Erinnerungen. Siegfried Wagner. Frankfurt/Mein: Peter Lang GmbH: Europāischer Verlagder Wissenschaften [in German]. 
13. Weichen für die Festspielstadt gestellt. Der Bayreuther Anwaltverein besteht seit 100 Jahren. Der Jurist Fritz Meyer paukte Winifred Wagner raus. Norbayerischer Kurier, Donnerstag 5. Juli 2011. Retrieved from: https://www.bayreuther-anwaltverein.de/files/media/downloads/Pressemitteilungen/05_07_2018_kul_16_bee36315e2.pdf [in German].

14. Weissweiler, E. (2013). Erbin des Feuers. Friedelind Wagner Eine Spurensuche. München: Pantheon Verlag [in German]. 